\title{
MicroRNA-495 Ameliorates Cardiac Microvascular Endothelial Cell Injury and Inflammatory Reaction by Suppressing the NLRP3 Inflammasome Signaling Pathway
}

\author{
Tao Zhou Dao-Kang Xiang Sui-Ning Li Lie-Hong Yang Lu-Fang Gao \\ Chao Feng
}

Department of Cardiac Surgery, Guizhou Provincial People's Hospital, Guiyang, China

\section{Key Words}

MicroRNA-495 • NLRP3 inflammasome signaling pathway • Endothelial cell • Inflammation reaction

\begin{abstract}
Background/Aims: In recent years, microRNA-495 (miR-495) has been reported to be a tumor-suppressor miR that is down-modulated in cancers. However, its potential mechanism remains unknown. Therefore, this study aimed to demonstrate the role of miR-495 in cardiac microvascular endothelial cell (CMEC) injury and inflammatory reaction by mediating the pyrin domain-containing 3 (NLRP3) inflammasome signaling pathway. Methods: Overall, 40 mice were assigned into myocardial ischemia/reperfusion injury (MIR) and sham groups. After model establishment, the levels of troponin T (TnT), troponin I (TnI), N-terminal pro$B$-type natriuretic peptide (NT-proBNP), creatine kinase isoenzyme MB (CK-MB), myoglobin (MYO), tumor necrosis factor-alpha (TNF- $\alpha$ ), and interleukin 1beta (IL-1 $\beta$ ) were detected by Enzyme-Linked Immunosorbent Assay (ELISA). Apoptosis was evaluated using Terminal deoxy (d)-UTP nick end labeling (TUNEL) staining, the level of NLRP3 protein was determined by immunohistochemical assay, and miR-495 was detected by in situ hybridization (ISH). The infarct size was determined using 2, 3, 5-triphenyltetrazolium chloride (TTC) staining. The expression of miR-495 and the mRNA and protein levels of NLRP3, TNF- $\alpha$, IL-1 $\beta$, IL-18 and caspase- 1 were evaluated by RT-qPCR and western blot analysis. After transfection, the cells were treated with a miR-495 mimic, a miR-495 inhibitor, or siNLRP3. Cell proliferation was measured by the 3-(4, 5-dimethylthiazol-2-yl)-2, 5-diphenyltetrazolium bromide (MTT) assay and cell cycle and apoptosis by flow cytometry. Results: Mice with myocardial I/R injury had elevated levels of TnT, TnI, NT-proBNP, CK-MB, MYO, TNF- $\alpha$ and IL-1 $\beta$; enhanced cell apoptosis; increased expression of NLRP3, TNF- $\alpha$, IL-1 $\beta$, IL-18 and caspase- 1 ; and decreased miR-495 expression. MiR-495 was confirmed to target NLRP3. Moreover, miR-495 reduced the mRNA and protein levels of NLRP3, TNF- $\alpha$, IL-1 $\beta$, IL-18 and caspase- 1 , inhibited cell apoptosis
\end{abstract}




\section{Cellular Physiology Cell Physiol Biochem 2018;49:798-815 \begin{tabular}{ll|l} 
DOI: 10.1159/000493042 & O 2018 The Author(s). Published by S. Karger AG, Basel \\
www.karger.com/cpb
\end{tabular} \\ Zhou et al.: miR-495 Acts on Mmvecs Via NLRP3 Inflammasome Pathway}

and decreased cells at the $G_{0} / G_{1}$ phase while improving cell proliferation and increasing cells at the S phase. However, the effects of NLRP4 were proved to be reciprocal. Conclusion: In conclusion, the current study indicated that miR-495 improved CMEC injury and inflammation by suppressing the NLRP3 inflammasome signaling pathway.

(C) 2018 The Author(s)

Published by S. Karger AG, Basel

\section{Introduction}

During myocardial ischemia-reperfusion, endothelial cells (ECs) are directly exposed to the hypoxia, which leads to injury [1]. For cell injury resulting from trauma, several procedures should be initiated simultaneously to achieve an acute inflammatory response designed to protect sustained tissue infection and damage and to recover and maintain tissue homeostasis [2]. Vessel endothelium injury due to reactive oxygen species plays a key role in the pathogenesis of cardiovascular disorders [3]. Myocardial ischemia-reperfusion injury is characterized as a major factor in the morbidity and mortality correlated with coronary artery disease [4]. Acute myocardial infarction is a major cause of disability and death worldwide [5]. Moreover, it induces a serious inflammatory response that is critical for cardiac repair, which is involved in the pathogenesis of heart failure and post-infarction remodeling [6]. Aging is correlated with an increased incidence of myocardial infarction and impaired angiogenesis when shaping new capillary blood vessels from preexisting vessels [7]. Myocardial infarction leads to cardiomyocyte loss, which considerably exceeds the limited regenerative capacity in the mammalian myocardium and causes high morbidity and mortality [8]. Although there have been advancements in the emergency treatment of myocardial infarction, its early mortality and morbidity remain high [9]. In addition, inflammatory responses play a major role in the processes of tumor development, including promotion, initiation, invasion, malignant conversion and metastasis, and they respond to therapy and influence immune surveillance [10]. A previous study has indicated that microRNA (miRs) modulate diverse aspects of heart disease, including heart failure, remodeling, hypertrophy, and arrhythmia [11].

MiRs are defined as endogenous small RNAs of 21-25 nucleotides, which can pair with sites in 3' untranslated regions in mRNAs in protein-coding genes to downregulate their levels, and circulating miRNAs have been demonstrated as promising biomarkers for different pathologic situations [12]. MiR-495 was verified to be a tumor-suppressor miR that is downmodulated in the mixed lineage leukemia-rearranged leukemia [13]. In addition, miR-495 modulates proliferation and migration in non-small cell lung cancer by targeting metastasisassociated protein 3 [14]. The nucleotide-binding domain and leucine-rich repeat-containing (NLR) family, pyrin domain-containing 3 (NLRP3) inflammasome is a multiprotein complex that activates caspase 1 , leading to the processing and secretion of the pro-inflammatory cytokines interleukin-1beta (IL-1beta) and IL-18 [15]. The NLRP3 inflammasome is characterized as a critical element of the innate immune system in realizing viral infection, but the mechanism by which viruses activate this inflammasome remains unclear [16]. The NLRP3 inflammasome activation is involved in several inflammatory diseases [17]. Moreover, as the NLRP3 inflammasome plays an important role in initiating acute sterile inflammation, a recent study has indicated that NLRP3 inflammasome up-modulates and mediates myocardial ischemia/reperfusion damage [18]. However, few studies have clarified the correlation among miR-495, NLRP3 and cardiac microvascular endothelial cell (CMEC) injury and inflammation. Thus, this study aims to discuss the effect of miR-495 on CMEC injury and inflammation reaction by mediating the NLRP3 inflammasome signaling pathway. 


\section{Cellular Physiology Cell Physiol Biochem 2018;49:798-815 \begin{tabular}{ll|l} 
and Biochemistry Published onlıne: 30 August, 2018 & $\begin{array}{l}\text { (c) } 2018 \text { The Author(s). Published by S. Karger AG, Basel } \\
\text { www.karger.com/cpb }\end{array}$
\end{tabular}}

\section{Materials and Methods}

\section{Ethical statement}

The experimental procedures and animal use were approved by the animal ethics committee of Guizhou Provincial People's Hospital.

\section{Study subjects}

A total of 40 C57BL/6 mice ( $8 \sim 10$ weeks) of clean level, provided by the Fourth Military Medical University, were selected. The housing conditions of these mice were free feeding, free drinking water and natural light illumination at a temperature of $18 \sim 22^{\circ} \mathrm{C}$, with $40 \% \sim 70 \%$ relative humidity and noise $<50$ $\mathrm{dB}$. After adaptive feeding for 1 week, these mice were assigned into the myocardial ischemia/reperfusion (I/R) injury (MIR group) or the sham group, with 20 mice in each group.

\section{Model establishment}

The C57BL/6 mice in the MIR group were fixed by dorsal decubitus and anaesthetized by intraperitoneal injection with $30 \mathrm{mg} / \mathrm{kg}$ pentobarbital sodium (P3761, Sigma-Aldrich, St Louis, MO, USA). The mice were connected with II lead electrocardiogram and disinfected by $75 \%$ absolute ethanol on the cervico-thoracic region. Next, a 1-cm median incision was made under the neck, and blunt separation of the anterior cervical muscle group was conducted along the midline, followed by trachea exposure. Then, the mice were given a tracheal cannula. After successful intubation, the tubes were fixed by bushing, and assisted respiration was conducted for the mice by connecting a breathing machine. A longitudinal incision was made in the left sternum of the mice, and the fourth costal cartilage was cut at approximately $0.5 \mathrm{~cm}$ from the left border of the sternum to expose the heart. The non-invasive needle was used to suture at approximately $1 / 3$ point on the anterior descending branch of the left coronary artery at a depth of approximately $1.5 \mathrm{~mm}$. If the color of the distal part of the suture became darker, the ST segment of the electrocardiogram (ECG) was elevated, which indicated that a successful model had been established [19]. The mice of the sham group were threaded but not treated by ligation. The blood pressure and heart rate before and after model establishment were tested using a blood pressure measuring instrument.

\section{Enzyme-Linked Immunosorbent Assay (ELISA)}

After $24 \mathrm{~h}$ of successful model establishment, $0.5 \mathrm{ml}$ of blood samples was collected, kept in a 2-ml test tube, and placed in a refrigerator at $4^{\circ} \mathrm{C}$ for $15 \mathrm{~min}$. Next, the samples were centrifuged at $8000 \mathrm{r} / \mathrm{min}$ for 10 min to collect the serum. According to the instructions for the ELISA Kit, the serum levels of troponin T (TnT), troponin I (TnI), N-terminal pro-B-type natriuretic peptide (NT-proBNP), creatine kinase isoenzyme myocardial band (CK-MB), myoglobin (MYO), tumor necrosis factor-alpha (TNF- $\alpha$ ), and interleukin (IL)$1 \beta$ of supernatant were, respectively, detected using Ek-M20983, ml024897, Ek-M20071, Ek-M20515, ml101811, Ek-M21159 and Ek-M20166 ELISA Kits (all from Shanghai Enzyme Research Biotechnology Co., Ltd., Shanghai, China). The ELISA Kits were equilibrated at room temperature for $20 \mathrm{~min}$, and the washing liquid was prepared. After the standard product was dissolved, $100 \mu \mathrm{l}$ of it was added to a reaction plate to determine the standard curve. Additionally, $100 \mu \mathrm{l}$ of the sample to be tested was added to the reaction well for incubation at $37^{\circ} \mathrm{C}$ for $90 \mathrm{~min}$. The sample was washed, $100 \mu \mathrm{l}$ of biotinylated antibody working fluid was added, and the sample was incubated at $37^{\circ} \mathrm{C}$ for $60 \mathrm{~min}$. Next, the sample was washed again, and $100 \mu \mathrm{l}$ of enzyme-bound working fluid (protected from light) was added for further incubation at $37^{\circ} \mathrm{C}$ for $30 \mathrm{~min}$. The plates were washed 3 times and treated with $100 \mu \mathrm{l}$ of substrate before incubation in the dark at $37^{\circ} \mathrm{C}$ for $15 \mathrm{~min}$. Subsequently, stop buffer was rapidly added to the sample to terminate the reaction. The optic density (OD) values of each tube were tested at $450 \mathrm{~nm}$ via an enzyme marker (BioTek Synergy 2, Winooski, USA) within $3 \mathrm{~min}$. The standard curve was drawn according to the OD values to analyze the serum levels of TnT, TnI, NT-proBNP, CK-MB, MYO, TNF- $\alpha$, and IL-1 $\beta$.

\section{Hematoxylin-eosin (HE) staining}

Thirty minutes after the physiological index measurement, the mice were killed by breaking their necks, and the myocardial tissue was collected and frozen in liquid nitrogen. After preservation at $-80^{\circ} \mathrm{C}$, the paraffin blocks were pruned and cut into serial sections $(5 \mu \mathrm{m})$, which were then placed into an $80^{\circ} \mathrm{C}$ oven for $1 \mathrm{~h}$. After being cooled, the sections were dewaxed with xylene I for $10 \mathrm{~min}$ and xylene II for 5 


\section{Cellular Physiology Cell Physiol Biochem 2018;49:798-815

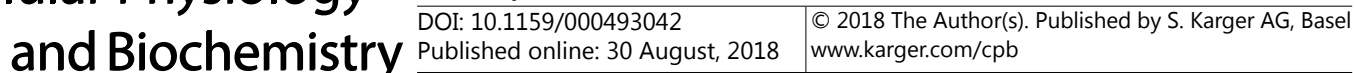 \\ Zhou et al.: miR-495 Acts on Mmvecs Via NLRP3 Inflammasome Pathway}

min and rinsed with absolute ethanol 2 times (each for $1 \mathrm{~min}$ ). The sections were dehydrated using 95\% gradient alcohol for $1 \mathrm{~min}, 90 \%$ gradient alcohol for $1 \mathrm{~min}$, and $85 \%$ gradient alcohol for $1 \mathrm{~min}$, and then rinsed with water for $2 \mathrm{~min}$. The sections were dyed by hematoxylin for $4 \mathrm{~min}$, rinsed with water for $1 \mathrm{~min}$, differentiated using hydrochloric alcohol for $10 \mathrm{~s}$ and rinsed and soaked in water for $5 \mathrm{~min}$. des, the sections returned blue by ammonia for $10 \mathrm{~min}$, dyed using eosin for $2 \mathrm{~min}$, and rinsed with water for $30 \mathrm{~s}$. Next, the sections were treated with $90 \%$ alcohol for $30 \mathrm{~s}$, 95\% I alcohol for $1 \mathrm{~min}, 95 \%$ II alcohol for $1 \mathrm{~min}$, absolute ethanol I for $2 \mathrm{~min}$ and absolute ethanol II for $2 \mathrm{~min}$, followed by dehydration using gradient alcohol, xylene I for $2 \mathrm{~min}$, xylene II for $2 \mathrm{~min}$, and xylene III for $2 \mathrm{~min}$. After the sections were mounted by neutral balsam, optical microscopy (regularity of optical microscope, NIKON, Tokyo, Japan) was performed to observe the pathological changes in myocardial tissues in a draught cupboard.

\section{In situ hybridization (ISH)}

The paraffin section of the myocardial tissues was sliced to $44-\mu \mathrm{m}$ thickness for the following experiment. The miRNA expression in the paraffin was assessed by ISH performed by BioGenex Laboratories Inc. (Fremont, CA) with miRNA ISH probes and Super Sensitive One-step Polymer- horseradish peroxidase (HRP) ISH detection kit on Xmatrx, the fully automated staining system (BioGenex Laboratories). In short, these tissues were pretreated using nucleic acid retrieval (NAR) solution at $85^{\circ} \mathrm{C}$ for $5 \mathrm{~min}$ and at $100^{\circ} \mathrm{C}$ for $20 \mathrm{~min}$. The tissues were incubated with the hybrid buffer at $42^{\circ} \mathrm{C}$ for $20 \mathrm{~min}$. Subsequently, the miRNA probe labeled with fluorescein (FAM) was utilized to measure miR-495 expression (100 nM). The nonspecific binding probe was rinsed and removed at $42^{\circ} \mathrm{C}$ The anti-fluorescein antibody was then added, followed by poly-HRP to detect the probe. Color visualization was performed using diaminobenzidine (DAB) and hematoxylin staining. Under the microscope, a positive cell count $<10 \%$ was considered negative, and a positive cell count $>10 \%$ was considered positive, as determined by a qualitative method.

\section{Terminal deoxy (d)-UTP nick end labeling (TUNEL) staining}

The TUNEL staining was applied via an in situ cell apoptosis detection kit (11684795910, Roche, Shanghai, China). The experiment followed the manufacturer's instructions, and the main steps were as follows: the myocardium at the apex of the heart was conventionally dehydrated, fixed, embedded by paraffin and sectioned. A total of 5 paraffin sections were selected from each group, dewaxed by xylene, dehydrated by gradient ethanol, and rinsed with phosphate-buffered saline (PBS) (pH 7.2) 3 times with $5 \mathrm{~min}$ for each wash (the same as below). The sections were digested by $20 \mu \mathrm{g} / \mathrm{ml}$ protease $\mathrm{K}$ at $37^{\circ} \mathrm{C}$ for $30 \mathrm{~min}$, rinsed by $\mathrm{PBS}$, and suppressed by $3 \% \mathrm{H}_{2} \mathrm{O}_{2}$ for $30 \mathrm{~min}$. The sections were treated with $1 \%$ citric acid solution containing $0.1 \%$ TritonX-100 to remove contaminants located on the cell membrane surface, rinsed with PBS, incubated at $37^{\circ} \mathrm{C}$ for $60 \mathrm{~min}$, and then treated with $50 \mu \mathrm{l}$ of the TUNEL reaction mixture. Additionally, the sections were treated with HRP-labeled goat anti-rabbit antibody, incubated at $37^{\circ} \mathrm{C}$ for 30 min, stained with diaminobenzidine (DAB), dehydrated, hyalinized, mounted, and examined under a microscope. The color image analyzer (BI-2000) was applied for analysis. The sections were observed using a high-power objective lens $(\times 400)$. Five views were randomly selected around myocardial damage from each section for counting the number of apoptotic cells through TUNEL staining.

\section{Immunohistochemical assay}

The tissue was fixed using $10 \%$ formaldehyde solution, conventionally embedded by paraffin, and sliced into $4-\mu \mathrm{m}$-thick serial sections. The samples were dewaxed, dehydrated by gradient xylene-alcohol, repaired by $3 \% \mathrm{H}_{2} \mathrm{O}_{2}$ sodium citrate antigen solution, and then sealed by serum. Additionally, the samples were treated with rabbit anti NLRP3 monoclonal antibody (1: 200, Santa Cruz Biotechnology, Santa Cruz, USA), incubated at $37^{\circ} \mathrm{C}$ for $1 \mathrm{~h}$ and $4^{\circ} \mathrm{C}$ overnight, and rinsed by PBS 3 times (each for $3 \mathrm{~min}$ ). In addition, the samples were treated with biotinylated goat anti-rabbit secondary antibody solution (ready-to-use) and incubated at $37^{\circ} \mathrm{C}$ for $30 \mathrm{~min}$, followed by 3 PBS washes (each for $3 \mathrm{~min}$ ). The samples were treated with newly prepared DAB (Boster Biological Technology co. ltd, Hubei, China) staining solution for $1 \sim 2 \mathrm{~min}$, followed by 3 PBS washes (each for $2 \mathrm{~min}$ ). The samples were re-stained by hematoxylin (Keygen Biological Technology Co. Ltd, Jiangsu, China) for 1 min, dehydrated, permeabilized, and mounted by neutral balata. The known positive section was viewed as the positive control, and PBS solution replaced the first antibody as the negative control. The standards of judgement were as follows: Five high-power visual fields (regularity of optical microscope, NIKON, Tokyo, Japan) were selected, with a total of approximately 200 cells in each 


\section{Cellular Physiology Cell Physiol Biochem 2018;49:798-815 \begin{tabular}{l|l|l} 
and Biochemistry Published online: 30 August, 2018 & $\begin{array}{l}\text { @ } 2018 \text { The Author(s). Published by S. Karger AG, Basel } \\
\text { www.karger.com/cpb }\end{array}$ \\
\hline
\end{tabular}}

field, and the positive cells with the brown or yellow cytoplasm were counted. The rate of NLRP3-positive cells in each field = the number of NLRP3-positive cells in each field/the number of total cells in each field. The rate of NLRP3-positive cells for the whole slice was calculated as the mean \pm standard deviation.

\section{2, 3, 5-triphenyltetrazolium chloride (TTC) staining}

After perfusion, the hearts of mice were removed and crosscut into 5 pieces of 2-mm sections. After being flattened, the sections were added to a $1 \%$ TTC solution dissolved by $0.1 \mathrm{~mol} / \mathrm{L} \mathrm{PBS}$, incubated at $37^{\circ} \mathrm{C}$ in the dark for $20 \mathrm{~min}$, removed and added to $10 \%$ neutral formaldehyde prepared in $0.1 \mathrm{~mol} / \mathrm{L}$ PBS. The two sides of 4 sections were photographed at the $1^{\text {st }}, 2^{\text {nd }}, 3^{\text {rd }}$ and $4^{\text {th }}$ week after the TTC staining. The infarct size of the heart was counted via Photoshop cs6 (Adobe Systems, San Jose, CA, USA). Moreover, the infarct size $(\%)=$ infarct size/total area of transverse section $\times 100 \%$.

\section{Reverse transcription quantitative polymerase chain reaction ( $R T-q P C R$ )}

Trizol RNA (Invitrogen, Carlsbad, CA, USA) was applied to extract total RNA. Agarose gel electrophoresis was performed to examine the integrity of RNA. The $28 \mathrm{~S}$ and $18 \mathrm{~S}$ were bright, clear, sharp bands, and the brightness of the $28 \mathrm{~S}$ band was more than twice that of the $18 \mathrm{~S}$ band, suggesting the integrity of the RNS segment. The ratio of A260/A280 of RNA was 2.1 at $260 \mathrm{~nm}$ (A260), as detected by the spectrophotometric method. The result suggested the high-purity of RNA. Reverse transcription was conducted using the Primescript TMR Treagent Kit Sensiscript RT-Kit (RR037A, TaKaRa Biotechnology, Liaoning, China). The steps were as follows: the RNA extract was dissolved in $40 \mu \mathrm{l}$ of non-RNAase water; and to each $200-\mu \mathrm{l}$ thinwalled tube without RNAase were added $12 \mu \mathrm{l}$ of non-RNAase water, $2 \mu \mathrm{l}$ of OdT and $3 \mu \mathrm{l}$ of RNA sample. The samples were mixed, heated at $70^{\circ} \mathrm{C}$ for $5 \mathrm{~min}$, and cooled with ice water for $2 \mathrm{~min}$. The samples were treated with $1 \mu \mathrm{l}$ of dNTP, $1 \mu \mathrm{l}$ of RNA enzyme inhibitor, $5 \mu \mathrm{l}$ of $5 \times$ reverse transcription buffer, and $1 \mu \mathrm{l}$ of reverse transcriptase MMLV. After gently mixing evenly using a transferpettor, the samples were incubated in a warm bath at $37^{\circ} \mathrm{C}$ for $90 \mathrm{~min}$, heated at $70^{\circ} \mathrm{C}$ for $5 \mathrm{~min}$ to terminate the reaction, and then preserved on the ice-box for the following experiment. The real-time PCR instrument (ABI 7500, Applied Biosystems Inc. Carlsbad, CA, USA) was used to amplify the target band, and the PCR reaction system was $25 \mu$ including $2.5 \mu \mathrm{l}$ of $10 \times$ PCR Buffer, $1.5 \mu \mathrm{l}$ of $25 \mathrm{mmol} / \mathrm{L} \mathrm{Mgcl}_{2}, 0.5 \mu \mathrm{l}$ of $10 \mathrm{mmol} / \mathrm{L} \mathrm{dNTP}, 1 \mu \mathrm{l} / \mathrm{L}$ of $10 \mathrm{mmol} / \mathrm{L}$ forward primer, $1 \mu \mathrm{l} / \mathrm{L}$ of $10 \mathrm{mmol} / \mathrm{L}$ reverse primer, $0.5 \mu \mathrm{L} / \mathrm{L}$ of Taq, 2.0 cof cDNA, and $16 \mu$ sterile distilled water. The reaction conditions were as follows: 40 cycles of denaturation at $94^{\circ} \mathrm{C}$ for $5 \mathrm{~min}$, denaturation at $94^{\circ} \mathrm{C}$ for $30 \mathrm{~s}$, denaturation at $58^{\circ} \mathrm{C}$ for $45 \mathrm{~s}$, denaturation at $72^{\circ} \mathrm{C}$ for $30 \mathrm{~s}$, and finally extension at $72^{\circ} \mathrm{C}$ for $10 \mathrm{~min}$. All reactions included three duplicated wells. The U6 was considered the internal reference of miR-495 and glyceraldehyde-3-phosphate dehydrogenase (GAPDH) for the other genes. The $2^{-\Delta \Delta \mathrm{Ct}}$ method [20] was used to determine the miR-495 expression and the mRNA expressions of NLRP3, TNF- $\alpha$, IL-1 $\beta$ and IL-18. The formula used was as follows:

the $\Delta \Delta \mathrm{CT}=\Delta \mathrm{T}$ (the CMECs injury group) $-\Delta \mathrm{Ct}$ (the control group)' of which $\Delta \mathrm{Ct}=\mathrm{Ct}$ sample RNA ${ }^{-\mathrm{Ct}}{ }_{\text {U6/GAPDH }}$. $\mathrm{Ct}$ was the number of cycles when the real-time fluorescence intensity of the reaction reached a set threshold. The cell experiments were conducted as above, and the primer sequences are shown in Table 1.

\section{Western blot analysis}

The total protein was extracted from the lysate (C0481, Sigma-Aldrich, St Louis, USA), and the protein was quantified the by bicinchoninic acid (BCA) method. The 10\% sodium dodecyl sulfate-polyacrylamide gel electrophoresis (SDSPAGE) gel was prepared, and each well had $20 \mu \mathrm{g}$ of the protein sample. The samples were mixed with sample loading buffer, boiled at $100^{\circ} \mathrm{C}$ for 5 min, incubated in an ice-bath, centrifuged and then added equivalently into each lane by a micro-sampler for electrophoretic separation.

Table 1. The primer sequences for RT-qPCR. Notes. RT-qPCR, reverse transcription quantitative polymerase chain reaction; miR-495, microRNA-495; NLRP3, pyrin domain-containing 3; TNF- $\alpha$, tumor necrosis factor-alpha; IL-1 $\beta$, interleukin 1 beta; IL$18 \beta$, interleukin 18beta; GAPDH, glyceraldehyde-3phosphate dehydrogenase

\begin{tabular}{lc}
\hline & Sequences (5'-3') \\
\hline miR-495 & Forward: AAACAAACATGGTGCA \\
NLRP3 & Feverse: GAGCAGGCTGGAGAA \\
& Reverse: CATGACCCGCCCGACAATAGG \\
TNF- $\alpha$ & Forward: CGAGTGACAAGCCCGTAGAC \\
& Reverse: GGATGAACACGCCAGTCGCC \\
IL-1 $\beta$ & Forward: GAAGCTCACCTTTTGACAGTG \\
IL-18 $\beta$ & Reverse: TGCATGCTCTCGCTAGGACAG \\
Caspase-1 & Reverse: GCCCACGCGTCTAACTTTGATGTAAGTTAGT \\
& Forward: TGGAAGGTAGGCAAGACT \\
U6 & Reverse: ATAGTGGGCATCTGGGTC \\
& Forward: GCTTCGGCAGCACATATACTAAAAT \\
GAPDH & Reverse: CGCTTCACGAATTTGCGTGTCAT \\
& Forward: GACCTGAAAGCTCCGTCTA \\
& Reverse: AGGCCCTGGGTGCTGCTGT
\end{tabular}




\section{Cellular Physiology Cell Physiol Biochem 2018;49:798-815

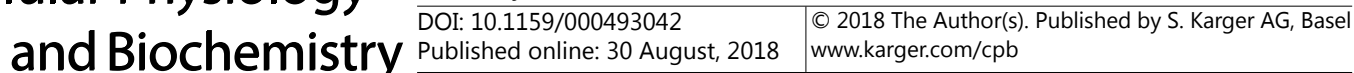 \\ Zhou et al.: miR-495 Acts on Mmvecs Via NLRP3 Inflammasome Pathway}

Subsequently, the protein on the gel was transferred into a nitrocellulose membrane. The membrane was blocked using 5\% non-fat milk powder for $1 \mathrm{~h}$ and treated with the rabbit anti-NLRP3 (ab214185, Abcam, Cambridge, MA, USA) (1: 500), rabbit anti-TNF- $\alpha$ (ab1793, Abcam, Cambridge, MA, USA) (1: 500), rabbit anti-IL-1 $\beta$ (ab200478, Abcam, Cambridge, MA, USA) and rabbit anti-IL-18 $\beta$ (ab71495, Abcam, Cambridge, MA, USA) (1: 500), followed by incubation at $4^{\circ} \mathrm{C}$ overnight. The membranes were washed with Trisbuffered saline-Tween (TBST) 3 times (each for $15 \mathrm{~min}$ ) the next day. The membranes were incubated with HRP-labeled goat anti-rabbit IgG (Beijing ComWin Biotech Co., Ltd., Beijing, China) (diluted by 1: 500) at room temperature for $1.5 \mathrm{~h}$, followed by TBST washing. The chemiluminescence method (NCI4106, Pierce Biotechnologies, Rockford, IL, USA) was applied to observe the protein expression. Beta-actin ( $\beta$-actin) was considered the internal reference, the first antibody was the mouse anti- $\beta$-actin (ab8226, Abcam, Cambridge, MA, USA) (1: 500), the second antibody was the HRP-labeled goat anti-rabbit IgG (1: 2000) (Beijing ComWin Biotech Co., Ltd., Beijing, China), and the method of incubation was the same as above. The relative expressions of NLRP3, TNF- $\alpha$, IL-1 $\beta$ and IL-18 were calculated as the ratio of the absorbance value of the bands for NLRP3, TNF- $\alpha$, IL-1 $\beta$ and IL-18 and the value of the $\beta$-actin band. Additionally, the gray level was analyzed by the ImageJ (Bio-rad) software, and the cell experiments adopted the same method as above.

\section{Cell culture, grouping and transfection}

The collected hearts were soaked in plates containing PBS and heparin for $5 \mathrm{~min}$, the hearts were taken out and rinsed with sterile PBS 3 times. After rinsing, the epicardial membranes were removed by ophthalmic scissors, and the myocardial tissue was sheared. The samples were treated with $3 \mathrm{ml}$ of type II collagenase (40508ES60, YEASEN, USA) and digested in a water bath for 6 min. Next, the samples were treated with equal volumes of pancreatin (C0201, Beyotime Biotechnology Inc., Shanghai, China) and digested in a water bath at $37^{\circ} \mathrm{C}$ for $25 \mathrm{~min}$. After digestion, the samples were treatede with Dulbecco's Modified Eagle Medium (DMEM) culture solution containing fetal bovine serum to terminate the digestion. The samples were filtered using a $100-\mu \mathrm{m}$ strainer, and the filtrate was centrifuged at $2000 \mathrm{r} / \mathrm{min}$ for 10 min at room temperature with the supernatant discarded. The cells were suspended in a complete culture medium and cultured in a $5 \% \mathrm{CO}_{2}$ cell incubator at $37^{\circ} \mathrm{C}$. On the day before transfection, the cells were placed on the 12-well plates for reaching 70\% fusion. In addition, 50 pmol of has-miR-495 mimic, hsamiR-495 inhibitor, siNLRP3 plasmid and NLRP3 plasmid (Shanghai GenePharma Co., Ltd., Shanghai, China) were added to 2-ml centrifuge tubes, respectively, followed by the addition of $100 \mu \mathrm{l}$ of Opti-MEM (Thermo Fisher Scientific, MA, USA), respectively, in each group. Next, $1 \mu \mathrm{l}$ of lipo2000 reagent (Thermo Fisher Scientific, MA, USA) was diluted in $50 \mu \mathrm{l}$ of Opti-MEM. The diluted reagent was mixed evenly and placed for $5 \mathrm{~min}$; next, the plasmid and lipo2000 diluent were mixed at room temperature for $20 \mathrm{~min}$. The lipo2000 mixture was added into corresponding cell plates. Moreover, the cells were cultured for $6 \mathrm{~h}$, followed by the replacement of the new culture medium. After transfection for $48 \mathrm{~h}$, the cells were collected and assigned to the normal group (cells from normal mice, without transfection), the blank group (cells from model mice, without transfection), the negative control (NC) group (transfected with the empty plasmid), the miR-495 mimic group (transfected with miR-495 mimic plasmid), the miR-495 inhibitor group (transfected with miR-495 inhibitor plasmid), the siNLRP3 group (transfected with siNLRP3 plasmid), the pcDNA3.1-NLRP3 group, or the miR-495 inhibitor + siNLRP3 group (transfected with inhibitor and siNLRP3 plasmid) for subsequent experimental analysis.

\section{Construction of overexpression vector of NLRP3 gene}

The RNA from the cells was extracted by the Trizol method, and NLRP3 sequences were designed for the RT-PCR reaction. The reaction conditions were as follows: at $94^{\circ} \mathrm{C}$ for $3 \mathrm{~min}, 94^{\circ} \mathrm{C}$ for $30 \mathrm{~s}, 60^{\circ} \mathrm{C} \mathrm{for}$ $30 \mathrm{~s}, 72^{\circ} \mathrm{C}$ for $30 \mathrm{~s}$ with 30 cycles, and $72^{\circ} \mathrm{C}$ for $10 \mathrm{~min}$. The $1.5 \%$ agarose gel electrophoresis method was used to observe the results and separate the PCR products. Subsequently, the products were recovered and purified according to the method provided by Gel Recovery Kit. The recovered products were connected with pcDNA3.1/VS-His-TOPO eukaryotic expression vector (K480001, Invitrogen Corporation, Carlsbad, CA, USA). Next, the samples were transformed into TOP10 competent bacteria (C404003, Invitrogen Corporation, Carlsbad, CA, USA). The positive clones were selected, and the plasmids were identified by sequencing. 


\section{Cellular Physiology Cell Physiol Biochem 2018;49:798-815 \begin{tabular}{ll|l} 
and Biochemistry Published onlıne: 30 August, 2018 & $\begin{array}{l}\text { (c) } 2018 \text { The Author(s). Published by S. Karger AG, Basel } \\
\text { www.karger.com/cpb }\end{array}$
\end{tabular}}

\section{Bioinformatics websites and dual-luciferase reporter gene assay}

The microRNA.org website was applied to test the target gene of miR-495 and to verify whether miR495 targeted and suppressed NLRP3. The full length of the 3'UTR region of the NLRP3 amplification gene was cloned. The PCR products were introduced and cloned downstream of polyclonal sites of pmirGLO Luciferase (Promega, Madison, WI, USA) via the endonuclease sites SpeI and Hind III to construct a pNLRP3wide-type (Wt) group. The binding site between miR-495 and the target gene was predicted by the target gene database, and a sequence mutation was created to construct a pNLRP3-Mutant (Mut) vector. The renilla luciferase reporter vector pRL-TK (TaKaRa Biotechnology, Liaoning, China) was considered the internal reference. The miR-495 mimics and NC were each transfected with the luciferase reporter vector into the cells. Additionally, the dual-luciferase reporter gene assay was performed according to the dual-luciferase reporter assay system (Promega, Madison, WI, USA).

\section{3-(4, 5-dimethylthiazol-2-yl)-2, 5-diphenyltetrazolium bromide (MTT) assay}

The mesothelial cells at logarithmic growth phase after transfection for $24 \mathrm{~h}$ were inoculated in 96well plates $\left(1 \times 10^{5}\right.$ cells $\left./ \mathrm{mL}\right)$. According to the experimental grouping, each group had 8 wells and $100 \mu \mathrm{l}$ cells in each well, which were then cultured in a $5 \% \mathrm{CO}_{2}$ cell incubator at $37^{\circ} \mathrm{C}$. After culturing for $24 \mathrm{~h}, 48 \mathrm{~h}$ and $72 \mathrm{~h}$, the cells were enabled to adhere completely and cultured in starvation in $1 \%$ fetal calf serum (FCS) 1640 culture medium overnight. Each group was treated with $2 \mathrm{mg} / \mathrm{mL}$ MTT solution and further cultured for $4 \mathrm{~h}$. Subsequently, a dimethylsulfoxide (DMSO) (Beijing Chemical Works, Beijing, China) solution was added and oscillated for $10 \mathrm{~min}$ to fully dissolve the crystals. The optical density (OD) values at $570 \mathrm{~nm}$ for each well were detected by a microplate reader (model 680, Bio-Rad, Hercules, CA, USA). The MTT curve was drawn with the OD values as the $\mathrm{Y}$-axis and the interval time as the $\mathrm{X}$-axis. The experiment was repeated 3 times.

\section{Flow cytometry}

After transfection for $48 \mathrm{~h}$, the culture medium was abandoned, and the cells were rinsed with PBS once and digested using $0.25 \%$ trypsin solution with the digested solution discarded. The cells were added to the culture medium containing serum to terminate the digestion, at which point the cells shrunk and became a circle under the microscope. Next, the cells were blown and hit to remove the cell walls and prepare a cell suspension. The cell suspension was centrifuged at $1000 \mathrm{r} / \mathrm{min}$ for $5 \mathrm{~min}$ with the supernatant discarded. Next, the cells were rinsed with a balanced salt solution PBS twice, filtered using a filter with $60 \mu \mathrm{m}$ of aperture, fixed with $70 \%$ pre-cooled ethanol for $30 \mathrm{~min}$, centrifuged, and then collected. After being rinsed by the balanced salt solution PBS, the cells were treated with $1 \%$ propidium iodide (PI) containing RNA enzyme for staining for $30 \mathrm{~min}$ and rinsed by balanced salt solution PBS twice to remove the PI solution. The balanced salt solution PBS was used to adjust the volume to $1 \mathrm{ml}$, and the cells were filtered by a filter with $60 \mu \mathrm{m}$ of aperture. Additionally, the samples were placed in a BD-Aria flow cytometry (FACSCalibur, Beckman Coulter, Inc., Chaska, MN, USA) for cell cycle detection with 3 samples for each group, and the experiment was repeated thrice.

After transfection for $48 \mathrm{~h}$, the cells were digested by pancreatin without ethylenediaminetetraacetic acid (EDTA), collected into flow tubes, and centrifuged with the supernatant discarded. Next, the cells were rinsed with cold PBS 3 times and centrifuged, and the supernatant was discarded. The Annexin-V-FITC, PI, and HEPES $(1: 2: 50)$ buffer solution was prepared for the Annexin-V-FITC/PI dye solution according to the instructions for the Annexin-V-FITC cell apoptosis assay kit (C1065, Beyotime Biotechnology Inc., Shanghai, China). A total of $1 \times 10^{6}$ cells was suspended in each $100 \mu \mathrm{l}$ of dye solution, oscillated, mixed and incubated at room temperature for $15 \mathrm{~min}$. Then, $1 \mathrm{ml}$ of 4-(2-hydroxyethyl)-1-piperazineethanesulfonic acid (HEPES) buffer solution was added to the cells, oscillated, and mixed. Flow cytometry was performed to record the excitation wavelength at $488 \mathrm{~nm}$, and the 525 and $620 \mathrm{~nm}$ bandpass filter were excited to detect FITC and PI fluorescence, respectively, and to evaluate cell apoptosis.

\section{Statistical analysis}

The SPSS 21.0 statistical software (IBM Corp., Armonk, NY, USA) was utilized for statistical analysis. Measurement data were presented as the mean \pm standard deviation. The t test was adopted for comparison between two groups. The one-way analysis of variance (ANOVA) analysis was applied for comparisons among multi-groups. $P<0.05$ indicated a statistically significant difference. 


\section{Cellular Physiology Cell Physiol Biochem 2018;49:798-815 \begin{tabular}{ll|l} 
and Biochemistry Published online: 30 August, 2018 & $\begin{array}{l}\text { (c) } 2018 \text { The Author(s). Published by S. Karger AG, Basel } \\
\text { www.karger.com/cpb }\end{array}$
\end{tabular}}

\section{Results}

The blood pressure and heart rate of mice before and after model establishment

First, the blood pressure and heart rate of mice were measured both before and after model establishment for comparison. There were 15 mice with a $75 \%$ success rate for model establishment. After model establishment, the heart rate had no significant change $(P>$ 0.05), and the blood pressure was significantly declined $(P<0.05)$ (Table 2).

An increase of levels of TnT, TnI, NT-proBNP, CK-MB, MYO, TNF- $\alpha$ and IL-1 $\beta$ are observed in mice with myocardial I/R injury

Next, the TnT, TnI, NT-proBNP, CK-MB, MYO, TNF- $\alpha$ and IL- $1 \beta$ s serum levels were determined in each group by ELISA. Compared with the sham group, the serum levels of TnT, TnI, NT-proBNP, CK-MB, MYO, TNF- $\alpha$ and IL-1 $\beta$ in the MIR group obviously increased (all $P$ $<0.05$ ) (Table 3). Therefore, mice with myocardial I/R injury have higher levels of TnT, TnI, NT-proBNP, CK-MB, MYO, TNF- $\alpha$ and IL-1 $\beta$.

Histopathological observation of myocardial tissue in mice with myocardial I/R injury

Subsequently, HE staining was utilized to observe the histopathological features of the myocardial tissue of mice with myocardial I/R injury. The results of the HE staining showed that the sham group had neatly arranged myocardial cells without obvious hyperplasia and hypertrophy, relatively balanced nuclear sizes, and no obvious hyperplasia of collagen fibers. However, the myocardial cells of the MIR group were in disorderly arrangement with obvious hyperplasia and hypertrophy and obviously increased hyperplasia of collagen fibers (Fig. 1).

Mice with myocardial I/R injury have increased cell apoptosis rate

TUNEL staining was applied for determining the effect of myocardial I/R injury on apoptosis. As shown in Fig. 2, the results of the TUNEL staining indicated that apoptotic positive cells were dark brown, with the nuclei showing atrophy, the chromatin gathered at the edge, and the cytoplasm was not stained. Apoptotic cells in the sham group [(1.29 \pm $0.11) \%]$ were lower than that in the MIR group $[(15.94 \pm 1.31) \%](P<0.05)$. Therefore, we can conclude that apoptosis was exaggerated by myocardial I/R injury.

Table 2. The heart rate and blood pressure before and after model establishment between the experiment and sham groups. Notes. *, $\mathrm{P}$ $<0.05$, compared with the sham group; MIR, myocardial ischemia/reperfusion injury

\begin{tabular}{lcc}
\hline Groups & Carotid-artery pressure/kpa & Heart rate/bpm \\
\hline Sham & $14.43 \pm 0.61$ & $532.36 \pm 117.60$ \\
MIR & $12.08 \pm 0.75^{*}$ & $533.74 \pm 84.30$ \\
\hline
\end{tabular}

Table 3. Changes in the levels of inflammatory factors (TnT, TnI, NT-proBNP, CK-MB, MYO, TNF- $\alpha$ and IL-1 $\beta$ ) in the sham and experiment groups. Notes. MIR, myocardial ischemia/reperfusion injury; TnT, Troponin T; TnI, troponin I; CK-MB, creatine kinase isoenzyme MB; MYO, myoglobin; NT-proBNP, N-terminal pro-B-type natriuretic peptide; TNF- $\alpha$, tumor necrosis factor-alpha; IL-1 $\beta$, interleukin 1beta; ${ }^{*}, \mathrm{P}<0.05$, compared with the sham group

\begin{tabular}{lccccccc}
\hline & TnT pg/ml & TnI g/ml & CK-MB ng/ml & MYO ng/ml & NT-proBNP pg/ml & TNF- $\alpha$ pg/ml & IL- $1 \beta \mathrm{pg} / \mathrm{ml}$ \\
\hline Sham & $0.02 \pm 0.01$ & $0.02 \pm 0.01$ & $0.11 \pm 0.02$ & $2.02 \pm 0.31$ & $118.51 \pm 12.41$ & $6.34 \pm 0.70$ & $1.64 \pm 0.13$ \\
MIR & $0.69 \pm 0.04^{*}$ & $1.16 \pm 0.10^{*}$ & $5.71 \pm 0.40^{*}$ & $8.53 \pm 0.68^{*}$ & $309.47 \pm 28.45^{*}$ & $88.13 \pm 11.27^{*}$ & $18.10 \pm 1.23^{*}$ \\
\hline
\end{tabular}

Fig. 1. HE staining results for the histopathological observation of the myocardial tissue of the mice in the sham and MIR groups. Note: HE, Hematoxylin-eosin; MIR, myocardial ischemia/reperfusion injury; (A) the sham group; (B) the MIR group.

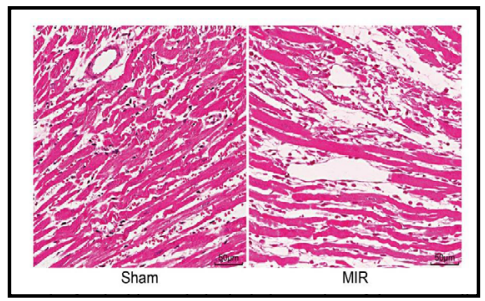




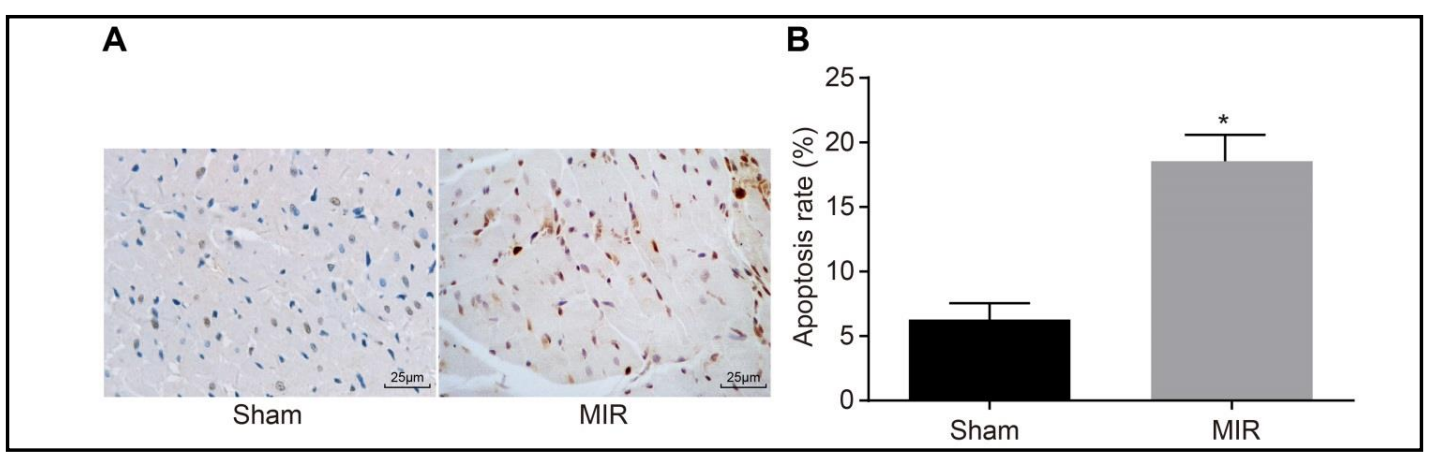

Fig. 2. TUNEL staining was utilized to assess the apoptosis rate in the mice in the sham and MIR groups. Note: miR-495, miRNA-495; TUNEL, terminal deoxy (d)-UTP nick end labeling; MIR, myocardial ischemia/ reperfusion injury; (A), TUNEL-staining pattern of myocardial tissues in the mice; (B), statistical chart of apoptosis of myocardial cells; *, $\mathrm{P}<0.05$, compared with the sham group.

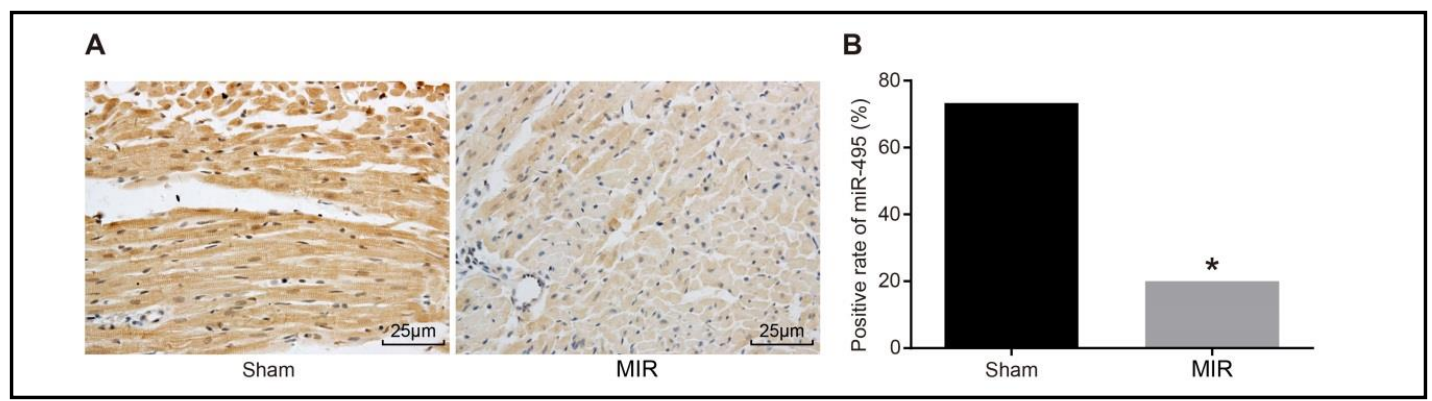

Fig. 3. ISH experiment showed that the positive rate of miR-495 expression was higher in the sham group than in the MIR group. Note: ISH, In situ hybridization; miR-495, miRNA-495; MIR, myocardial ischemia/ reperfusion injury; (A), expression of miR-495 in the sham group; (B), expression of miR-495 in the MIR group; (C), expression of miR-495 between the sham and MIR groups after in situ hybridization experiment; $*, \mathrm{P}<0.05$, compared with the sham group.

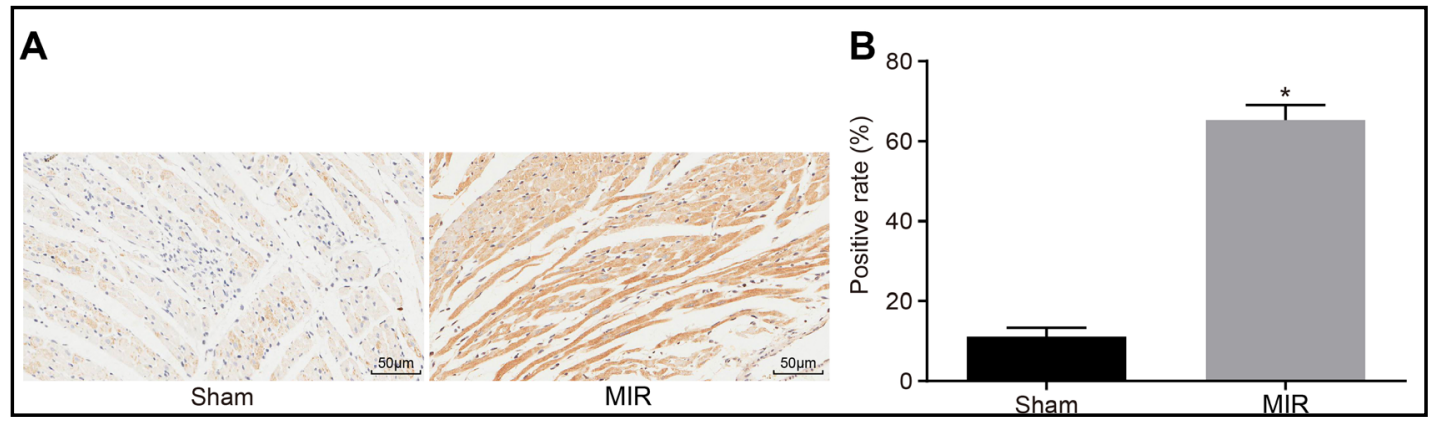

Fig. 4. Immunohistochemistry studies indicated that NLRP3 expression was higher in the MIR group than in the sham group. Note: MIR, myocardial ischemia/reperfusion injury; NLRP3, pyrin domain-containing 3; (A), Immunohistochemical staining chart of NLRP3 expression; (B), statistical chart of NLRP3 expression.

\section{The positive expression of miR-495 is lower in mice with myocardial I/R injury}

Since miR-495 has been reported to exhibit abnormal expression in myocardial diseases, its expression was detected by an in situ hybridization experiment. When the cytoplasm was visualized as blue-purple, the cells were considered to exhibit positive expression of miR-495. Of the 15 cases in the sham group, 3 positive cases were found to have a positive rate of $15.00 \%$, and in the 11 cases in the MIR group, 11 positive cases were identified to have a positive rate of $85.00 \%$. Compared to the sham group, the positive expression of miR495 increased significantly in the MIR group (Fig. 3). It is revealed that there is a decline of positive expression of miR-495 in mice with myocardial I/R injury.

\section{KARGER}


Positive expression of NLRP3 is lower in mice with myocardial I/R injury

NLRP3 had additionally been investigated in myocardial diseases with correlation with miRNAs; therefore, the next step was to measure the positive expression of NLRP3 in each group using immunohistochemistry. The CMECs characterized by different degrees of brown granules under a light microscope were the positive cells; otherwise, the results of staining showed the negative cells (Fig. 4). As shown in Fig. 4, the sham group exhibited a few NLRP3positive cells $(13.26 \pm 2.34) \%$, while the MIR group exhibited several NLRP3-positive cells $(64.19 \pm 4.31) \%$. Compared with the sham group, the positive rate of NLRP3 in the MIR group significantly increased $(P<0.05)$. These results suggested that in contrast to the expression of miR-195, that of NLRP3 demonstrated an opposite tendency in mice with myocardial I/R injury.

Mice with myocardial $I / R$ injury exhibited larger infarct size

TTC staining was utilized to estimate the infarct size of mice with myocardial I/R injury in each group. The results of

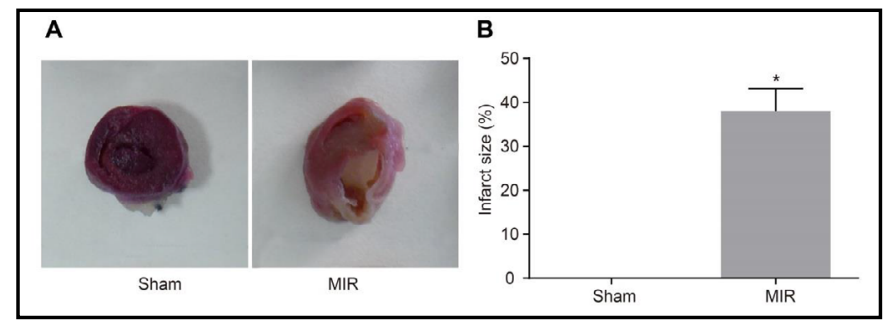

Fig. 5. TTC staining suggested that the infarct size was enlarged in mice with myocardial ischemia/reperfusion injury. Note: TTC, 2, 3, 5-triphenyltetrazolium chloride; MIR, myocardial ischemia/ reperfusion injury; (A), staining pattern of the myocardium; (B), statistical chart of the myocardial infarct size; ${ }^{*}, \mathrm{P}<0.05$, compared with the sham group.

Fig. 6. ELISA and western blot analysis were applied to determine the miR495 expression and mRNA and protein expression of NLRP3, TNF- $\alpha$, IL-1 $\beta, \quad$ IL-18 and caspase-1. The miR-495 expression was repressed, while the mRNA and protein expression
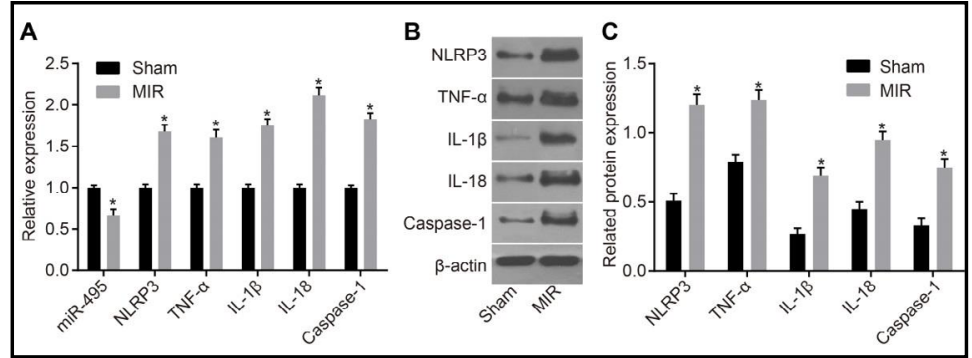
of NLRP3, TNF- $\alpha$, IL-1 $\beta$, IL-18 and caspase- 1 was enhanced in mice with myocardial ischemia/reperfusion injury. Note: ELISA, enzymelinked immunosorbent assay; MIR, myocardial ischemia/reperfusion injury. miR-495, microRNA-495; NLRP3, pyrin domain-containing 3; TNF- $\alpha$, tumor necrosis factor-alpha; IL-1 $\beta$, interleukin 1beta; IL-18, interleukin-18; $\beta$-actin, beta-actin; (A), western blotting map; (B), statistical chart of the protein expression of relative genes; (C), statistical chart of miR-495 expression and the mRNA expression of relative genes; *, $\mathrm{P}<0.05$, compared with the sham group.

Fig. 7. NLRP3 was identified as the target gene of miR-495. Note: MIR, myocardial ischemia/reperfusion injury; miR-495, microRNA-495; NLRP3, pyrin domaincontaining 3; Wt, Wide-type; Mut, Mutant; (A), sequences of the 3'-UTR region of the NLRP3 mRNA binding with miR-495; (B), expression of miR-495 in the pmTOR-Wt and pmTOR-Mut groups; $*, \mathrm{P}<0.05$, compared with the control group.

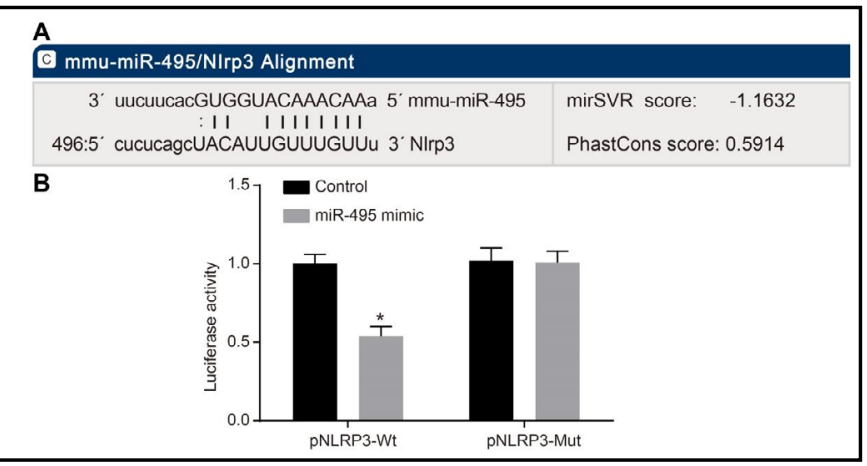

\section{KARGER}


Fig. 8. RT-qPCR outcomes revealed that miR-495 was negatively associated with the mRNA expression of NLRP3, TNF- $\alpha$, IL-1 $\beta$, IL-18 and caspase-1, while NLRP3 was positively associated with the mRNA expression of TNF- $\alpha$, IL-1 $\beta$, IL-18 and caspase-1. Note: RT-qPCR, reverse transcription quantitative polymerase chain reaction.; NC, negative control; miR-

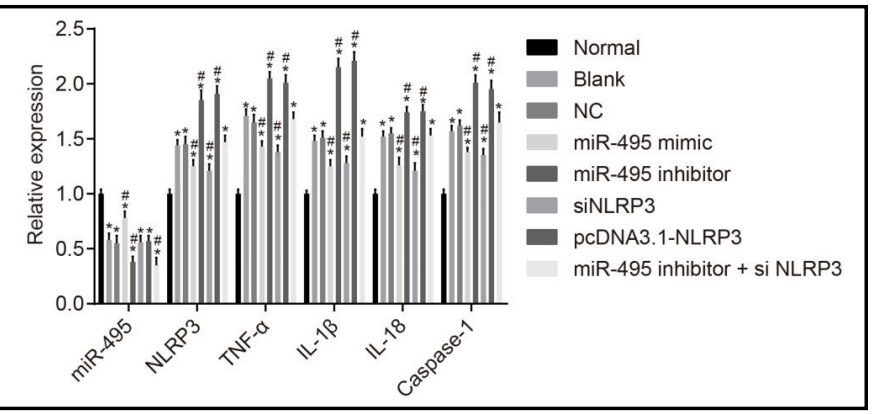
495, microRNA-495; NLRP3, pyrin domain-containing 3; TNF- $\alpha$, tumor necrosis factor-alpha; IL-1 $\beta$, interleukin 1beta; IL-18, interleukin-18; (A), miR-495 expression in each group; (B), expression of NLRP3, TNF- $\alpha$, IL-1 $\beta$, IL-18 and caspase-1; *, $\mathrm{P}<0.05$, compared with the normal group; \#, all $\mathrm{P}<0.05$, compared with the blank and NC groups.

Fig. 9. Western blot analysis demonstrated that miR-495 negatively correlated with the protein expression of NLRP3, TNF- $\alpha$, IL-1 $\beta$, IL-18 and caspase-1, and the opposite was found for NLRP3. Note: NC, negative control; miR-495, microRNA-495; NLRP3, pyrin domaincontaining 3 ; TNF- $\alpha$, tumor necrosis factor-alpha; IL-1 $\beta$, interleukin 1 beta; IL18, interleukin-18; (A), western blotting map; (B), statistical chart of protein expression; *, $\mathrm{P}<0.05$, compared with the normal group; \#, all $\mathrm{P}<0.05$, compared

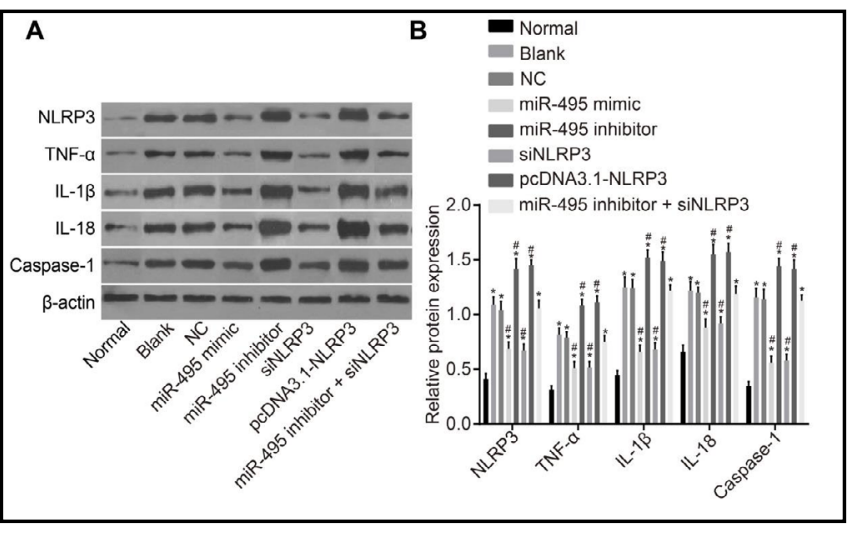
with the blank and NC groups.

the TTC staining showed that the normal myocardial tissue was stained red and that the infarction site was not stained (Fig. 5). The myocardial infarct size of the sham group was $0 \%$, which was lower than that in the MIR group [(37.98 \pm 2.15$) \%](P<0.05)$. It is obvious that mice with myocardial I/R injury exhibited increased myocardial infarct size.

Mice with myocardial I/R injury restrained the miR-495 expression while promoting the $m R N A$ and protein expression of NLRP3, TNF- $\alpha, I L-1 \beta, I L-18$ and caspase- 1

RT-qPCR and western blot analysis were utilized to measure the expression of related genes and proteins. Compared with the sham group, the miR-495 expression of the MIR group apparently decreased $(P<0.05)$; however, the mRNA and protein expression levels of NLRP3, TNF- $\alpha$, IL-1 $\beta$, IL-18 and caspase- 1 were increased (all $P<0.05$ ). Notably, the IL18 expression increased to a greater degree among the above five factors (Fig. 6). Thus, mice with myocardial I/R injury demonstrate lower miR-495 expression but higher NLRP3, TNF- $\alpha$, IL-1 $\beta$, IL-18 and caspase-1e expression.

\section{NLRP3 was verified as the target gene of miR-495}

The relationship between miR-495 and NLRP3 was investigated next. The biological prediction website microRNA.org showed that miR-495 targeted and suppressed NLRP3. There were sequences of the 3'-UTR region of the NLRP3 mRNA binding with miR-495 (Fig. 7A). Furthermore, the dual-fluorescent reporter gene system indicated that luciferase signal of the pmTOR-Wt co-transfection group in the miR-495 mimic group decreased markedly compared with the other groups $(P<0.05)$; however, the luciferase signal of pmTOR-Mut in each group showed no significant difference $(P>0.05)$ (Fig. 7B). Thus, miR-495 could target the NLRP3 mRNA via the negative regulation of its expression. 
MiR-495 suppressed NLRP3, TNF- $\alpha, I L-1 \beta, I L-18$ and caspase- 1 expression, whereas NLRP3 had the opposite effect on TNF- $\alpha, I L-1 \beta, I L-18$ and caspase- 1

In addition, the role of miR-495 on NLRP3 and the functions of miR-495 and NLRP3 on TNF- $\alpha$, IL-1 $\beta$, IL-18 and caspase- 1 were studied. Compared with the normal group, miR-495 expression decreased, but the mRNA expression of NLRP3, TNF- $\alpha$, IL-1 $\beta$, IL-18 and caspase-1 obviously increased in the blank, NC, miR-495 mimic, miR-495 inhibitor, miR-495 inhibitor + siNLRP3, siNLRP3, and pcDNA3.1-NLRP3 groups $(P<0.05)$. No significant difference was found in the mRNA expression of NLRP3, TNF- $\alpha$, IL-1 $\beta$, IL-18 and caspase- 1 among the blank, NC, and miR-495 inhibitor + siNLRP3 groups or between the miR-495 inhibitor and pcDNA3.1NLRP3 groups (all $P>0.05$ ). Compared with the blank and the NC groups, the miR495 expression increased considerably in the themiR-495 mimic group $(P<0.05)$, but the result was opposite to that in the miR-495 inhibitor group $(P<0.05)$. Compared with the blank and NC groups, the mRNA expression of NLRP3, TNF- $\alpha$, IL-1 $\beta$, IL-18

Table 4. Changes in cell cycle distribution in each group. Notes. NC, negative control; miR-495, microRNA-495; NLRP3, pyrin domaincontaining 3 * $^{*} \mathrm{P}<0.05$, compared with the normal group; \#, all $\mathrm{P}<$ 0.05 , compared with the blank and the NC groups

\begin{tabular}{lccc}
\hline Groups & $\mathrm{G}_{0} / \mathrm{G}_{1 / /} / \%$ & $\mathrm{~S} / \%$ & $\mathrm{G}_{2} / \%$ \\
\hline Sham & $40.23 \pm 3.10$ & $35.61 \pm 2.90$ & $24.16 \pm 5.74$ \\
Blank & $64.45 \pm 4.23^{*}$ & $22.31 \pm 2.14^{*}$ & $13.24 \pm 2.30^{*}$ \\
NC & $65.21 \pm 5.13^{*}$ & $20.14 \pm 1.63^{*}$ & $14.65 \pm 5.61^{*}$ \\
miR-495 mimic & $53.42 \pm 4.08^{*} \#$ & $30.21 \pm 2.49^{*} \#$ & $16.36 \pm 6.54^{*} \#$ \\
miR-495 inhibitor & $78.37 \pm 3.07^{*} \#$ & $16.53 \pm 1.22^{*} \#$ & $5.10 \pm 1.25^{*} \#$ \\
siNLRP3 & $52.34 \pm 3.21^{*} \#$ & $30.38 \pm 2.73^{*} \#$ & $17.28 \pm 4.86^{*} \#$ \\
pcDNA3.1-NLRP3 & $77.43 \pm 6.14^{*} \#$ & $15.86 \pm 1.26^{*} \#$ & $6.71 \pm 1.18^{*} \#$ \\
miR-495 inhibitor+ siNLRP3 & $62.34 \pm 3.57^{*}$ & $21.17 \pm 1.53^{*}$ & $16.49 \pm 3.88^{*}$ \\
\hline
\end{tabular}

Fig. 10. Cell proliferation was positively affected by the overexpression of miR-495 or silenced NLRP3, as determined by MTT assay. Note: MTT, 3-(4, 5 -dime thyl thiazol-2-yl)-2, 5-diphenyltetrazolium bromide; $\mathrm{NC}$, negative control; miR-495, microRNA-495; NLRP3, pyrin domain-containing 3 ; *, $\mathrm{P}<0.05$,

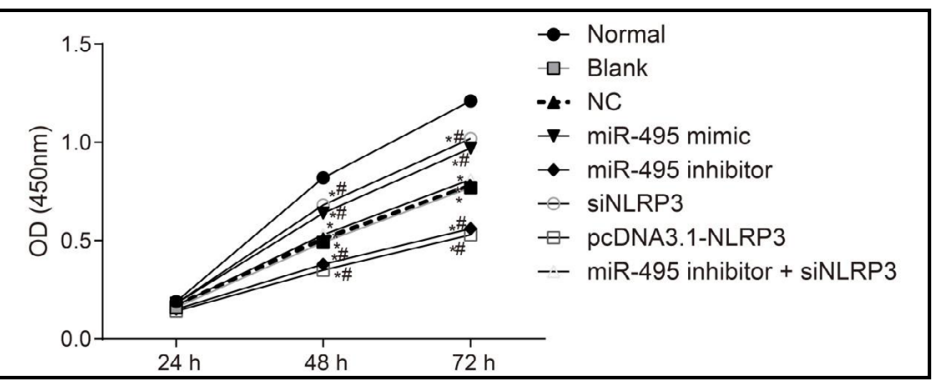
compared with the normal group; \#, all $\mathrm{P}<0.05$, compared with the blank and NC groups.

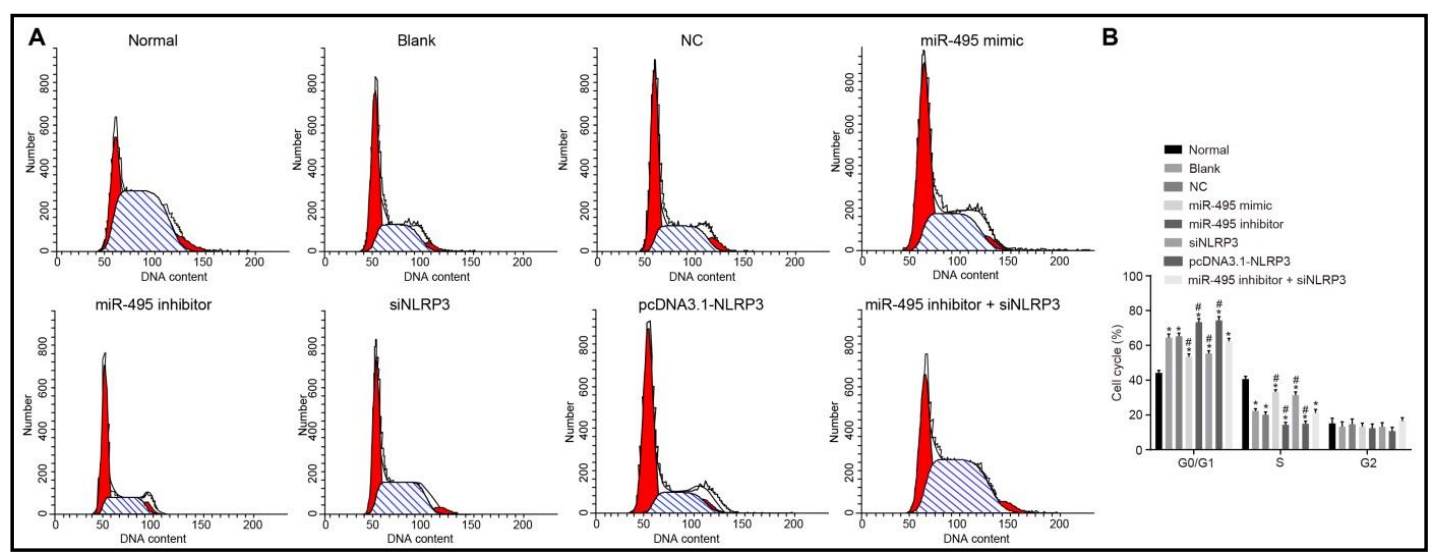

Fig. 11. Flow cytometry validated that the overexpression of miR-495 or silenced NLRP4 induced changes in cell cycle distribution. Note: NC, negative control; miR-495, microRNA-495; NLRP3, pyrin domain-containing 3; (A), the cycle distribution in each group; (B), statistical chart of the cell cycle; Channels (FL2-A) = 200; *, $\mathrm{P}<0.05$, compared with the normal group; \#, all $\mathrm{P}<0.05$, compared with the blank and the NC groups. 


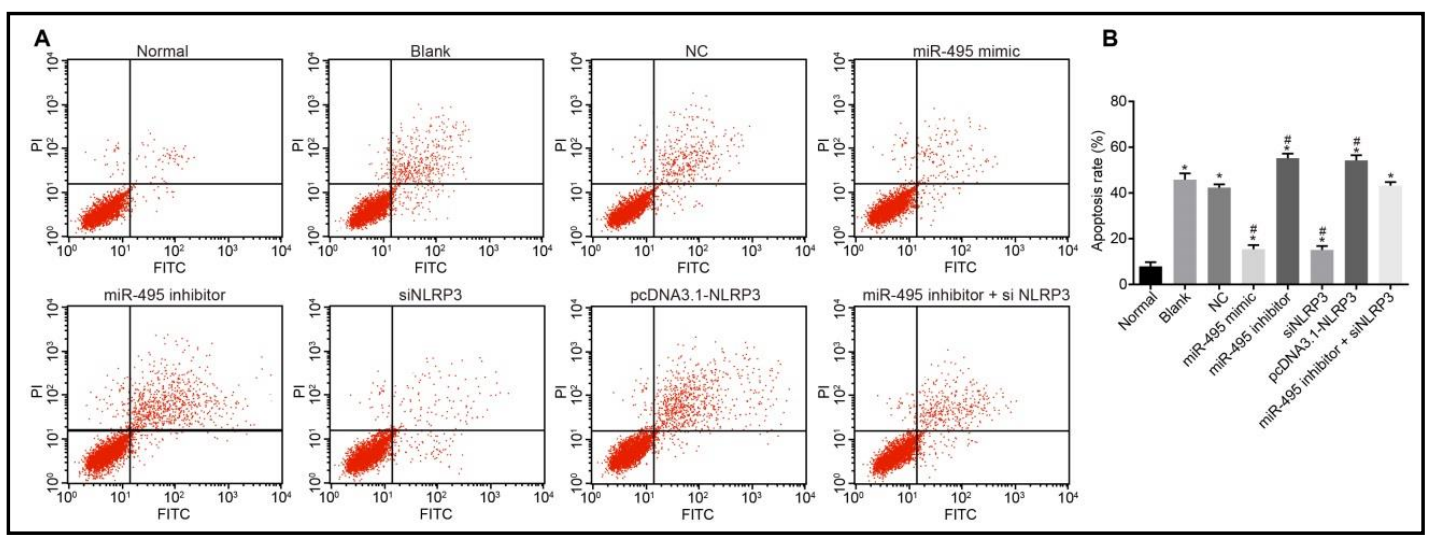

Fig. 12. Flow cytometry indicated that miR-495 overexpression and a low expression of NLRP3 caused suppression of cell apoptosis. Note: NC, negative control; miR-495, microRNA-495; NLRP3, pyrin domaincontaining 3; (A), cell apoptosis in each group; (B), statistical chart of cell apoptosis; *, $\mathrm{P}<0.05$, compared with the normal group; \#, all $\mathrm{P}<0.05$, compared with the blank and $\mathrm{NC}$ groups; $\&$, all $\mathrm{P}<0.05$, compared with the miR-495 inhibitor and pcDNA3.1-NLRP3 groups.

and caspase- 1 clearly decreased in the miR-495 mimic and siNLRP3 groups. In contrast, the mRNA expression of NLRP3, TNF- $\alpha$, IL-1 $\beta$, IL-18 and caspase- 1 increased significantly in the miR-495 inhibitor and pcDNA3.1NLRP3 groups (all $P<0.05$ ) (Fig. 8). Therefore, miR-495 negatively impacted the miRNA expression of NLRP3, TNF- $\alpha$, IL-1 $\beta$, IL-18 and caspase- 1 , whereas NLRP3 positively impacted TNF- $\alpha$, IL- $1 \beta$, IL-18 and caspase- 1 miRNA expression.

In addition to the mRNA expression, the protein expression of important factors was evaluated. The protein expression of NLRP3, TNF- $\alpha$, IL-1 $\beta$, IL-18 and caspase- 1 increased significantly in the blank, NC, miR-495 mimic, miR-495 inhibitor, miR-495 inhibitor + siNLRP3, siNLRP3, and pcDNA3.1-NLRP3 groups compared to the normal group $(P<0.05)$. No significant difference was observed in the protein expression of NLRP3, TNF- $\alpha$, IL-1 $\beta$, IL-18 and caspase- 1 among the blank, NC, and miR-495 inhibitor + siNLRP3 groups or between the miR-495 inhibitor and pcDNA3.1-NLRP3 groups (all $P>0.05$ ). Compared with the blank and the NC groups, the protein expression decreased clearly in the miR-495 mimic and siNLRP3 groups but increased in the miR-495 inhibitor and pcDNA3.1-NLRP3 groups (all $P<0.05$ ) (Fig. 9). The influence of miR-495 and NLRP3 on protein expression was the same as that observed for miRNA expression.

\section{Overexpression of miR-495 or silenced NLRP3 promoted cell proliferation}

The involvement of miR-495 and NLRP3 in cell proliferation was evaluated using the MTT assay. The cell proliferation increased with culture time. Compared with the normal group, the cell proliferation clearly declined in the blank, NC, miR-495 mimic, miR-495 inhibitor, miR-495 inhibitor + siNLRP3, siNLRP3 and pcDNA3.1-NLRP3 groups $(P<0.05)$. There was no obvious difference among the blank, NC and miR-495 inhibitor + siNLRP3 groups or between the miR-495 inhibitor and pcDNA3.1-NLRP3 groups $(P>0.05)$. Moreover, the cell proliferation increased significantly in the miR-495 mimic and siNLRP3 groups compared with the blank and NC groups (all $P<0.05$ ), but it obviously decreased in the miR495 inhibitor and pcDNA3.1-NLRP3 groups (all $P<0.05$ ) (Fig. 10). The conclusion was thus 


\section{Cellular Physiology Cell Physiol Biochem 2018;49:798-815 \begin{tabular}{l|l} 
DOI: 10.1159/000493042 & $\begin{array}{l}\text { O 2018 The Author(s). Published by S. Karger AG, Basel } \\
\text { www.karger.com/cpb }\end{array}$
\end{tabular} \\ Zhou et al.: miR-495 Acts on Mmvecs Via NLRP3 Inflammasome Pathway}

that cell proliferation can be accelerated via the upregulation of miR-495 or downregulation of NLRP3.

Overexpression of miR-495 or silenced NLRP3 prolonged the GO/G1 phase and shortened the $S$ phase

Changes in the $\mathrm{G}_{0} / \mathrm{G}_{1}$ phase and $\mathrm{S}$ phase were next evaluated using flow cytometry. Cells at the $\mathrm{G}_{0} / \mathrm{G}_{1}$ phase obviously increased, and cells at the $\mathrm{S}$ phase significantly decreased in the blank, NC, miR-495 mimic, miR-495 inhibitor, miR-495 inhibitor + siNLRP3, siNLRP3 and pcDNA3.1-NLRP3 groups compared to the normal group $(P<0.05)$. No significant changes in cells at the $G_{0} / G_{1}$ phase were observed among the blank, NC, and miR-495 inhibitor + siNLRP3 groups or between the miR-495 inhibitor and shNLRP3 groups $(P>0.05)$. Compared with the blank and NC groups, the miR-495 mimic and siNLRP3 groups clearly had fewer cells at the $\mathrm{G}_{0} / \mathrm{G}_{1}$ phase $(P<0.05)$ and apparently increased cells at the $S$ phase $(P<0.05)$. Meanwhile, cells at the $G_{0} / G_{1}$ phase in the miR-495 inhibitor and pcDNA3.1-NLRP3 groups exhibited no obvious difference $(P>0.05)$ (Fig. 11, Table 4). Therefore, increased miR-495 and repressed NLRP3 promotes cell cycle progression.

\section{Overexpression of miR-495 or silenced NLRP3 inhibited cell apoptosis}

Finally, differences in cell apoptosis caused by miR-495 and NLRP3 were detected by flow cytometry. Compared with the normal group, cell apoptosis significantly increased in the blank, NC, miR-495 mimic, miR-495 inhibitor, miR-495 inhibitor + siNLRP3, siNLRP3, and pcDNA3.1-NLRP3 groups $(P<0.05)$. No significant difference in apoptosis was observed among the blank, NC and miR-495 inhibitors + siNLRP3 groups or between the miR-495 inhibitor and pcDNA3.1-NLRP3 groups $(P>0.05)$. The miR-495 mimic and siNLRP3 groups demonstrated clearly decreased cell apoptosis, while the miR-495 inhibitor and pcDNA3.1NLRP3 groups showed the opposite results compared to the normal group (all $P<0.05$ ) (Fig. 12, Table 5). It is clear that the effects of increased miR-495 or silenced NLRP3 on cell apoptosis were opposite to those on cell proliferation.

\section{Discussion}

Myocardial infarction is reported to be the major cause of death in the world, and over the last two decades, coronary reperfusion therapy has been developed for managing acute myocardial infarction [21]. Endothelial cell damage caused by inflammatory factors plays a crucial role in the pathogenesis of numerous vascular diseases [22]. The total difference in the slope of the increase in systolic blood pressure per minute, the systolic blood pressure, and maximal systolic blood pressure during exercise in quintiles have been correlated with the risk of acute myocardial infarction [23]. In our study, we aimed to elucidate the effect of miR-495 on CMEC injury and inflammation reaction through mediating the NLRP3 inflammasome signaling pathway. Subsequently, our study concluded that the overexpression of miR-495 ameliorated CMEC injury and inflammation reaction by suppressing the NLRP3 inflammasome signaling pathway.

In our study, mice in the MIR group exhibited decreased blood pressure and increased infarct size, NLRP3-positive expression and levels of TnT, TnI, NT-proBNP, CK-MB, MYO, TNF- $\alpha$ and IL-1 $\beta$. Cardiac TnT tested with a strongly sensitive assay was correlated with structural heart diseases and the subsequent development of all-cause mortality [24]. Troponin is primarily used for detecting minor myocardial damage, whereas repeated measurements of CK and CK-MB are used to examine infarct size in patients with myocardial infarction; a very high relation was shown between the peak level and area under the curve of TnT, CK, and CKMB [25]. Meanwhile, MYO, an early indicator of acute myocardial infarction, plays a primary function in the urgent diagnosis for cardiovascular diseases [26]. Moreover, the mRNA and protein levels of NLRP3, TNF- $\alpha$, IL-1 $\beta$, IL-18 and caspase- 1 increased significantly, but miR495 expression decreased markedly in the experiment group. TNF- $\alpha$ has been indicated 


\section{Cellular Physiology Cell Physiol Biochem 2018;49:798-815 \begin{tabular}{ll|l} 
DOI: 10.1159/000493042 & $\begin{array}{l}\text { O 2018 The Author(s). Published by S. Karger AG, Basel } \\
\text { www.karger.com/cpb }\end{array}$
\end{tabular} \\ Zhou et al.: miR-495 Acts on Mmvecs Via NLRP3 Inflammasome Pathway}

to regulate brain injury, but remarkably little is clear about its influence on neurogenesis [27]. The infarct size in TNF- $\alpha$ knockout mice was obviously reduced compared to WT mice [28]. IL-1 $\beta$ and IL-18 are critical mediators in inflammation, and a defective regulation of their release might lead to serious diseases [29]. Furthermore, high IL-18 levels relate to an increased risk of cardiovascular disease (CVD) and a more serious prognosis in patients with constituted CVD [30].

Moreover, compared with the blank and NC groups, miR-495 expression was increased significantly in the miR-495 mimic group, while the mRNA expressions of NLRP3, TNF- $\alpha$, IL-1 $\beta$, IL-18 and caspase- 1 were decreased significantly in the miR-495 mimic and siNLRP3 groups. Inflammasomes are defined as multiple protein complexes that act as molecular platforms to induce caspase- 1 and control the maturation of a potent proinflammatory cytokine IL-1 $\beta$, pyroptosis and proinflammatory cell death [31]. The NLRP3 inflammasome is a multiprotein compound that comprises three types of proteins, NLRP3, ASC, and procaspase-1, and is involved in sensing pathogens and serious signals in the innate immune system [32]. TNF- $\alpha$ is crucially concerned with the pathogenesis and procedures of heart failure and myocardial ischemia/reperfusion injury [33]. The NLRP3 inflammasome also modulates IL-1 $\beta$ maturation and secretion in another disease of metabolic dysregulation: gout [34]. Active IL-1 $\beta$ is a vital product of the inflammasome and is cleaved via active caspase- 1 [35]. Activation of the NLRP3 inflammasome in calcineurin transgene mice improves systolic dysfunction and myocardial inflammation by producing the pro-inflammatory IL-1 $\beta$ [36]. NLRP3 plays a protective role in age-related macular degeneration via the induction of IL-18 through drusen components [37]. In endothelial cells, the NLRP3 inflammasome exhibits a significant initiating mechanism, and its activation may accelerate the development of endothelial dysfunction or atherogenic pathology by inducing plasma trimethylamine- $\mathrm{N}$ oxide (TMAO) [38]. The repression of the NLRP3 inflammasome is a critical factor in I/R or inflammation by correlation with SIRT1, which was proved to be involved in both preventing cells from injury induced by various stress and improving endothelial precursor cell function $[39,40]$. Activating the NLRP3 inflammasome signaling can promote atherosclerosis pathogenesis via the overexpression of inducible endothelial-specific GPR124 [41]. In a previous study of ischemic acute kidney injury (AKI), the deficiency of NLRP3 served as a protective factor against mortality, renal dysfunction, and neutrophil influx of mice [42]. Furthermore, our study demonstrated that NLRP3 was the target gene of miR-495, which suggests that overexpressed miR-495 may have the same function as silenced NLRP3.

Finally, we observed that cell proliferation significantly increased but cell apoptosis decreased in the miR-495 mimic and siNLRP3 groups, and the opposite results were found in the miR-495 inhibitor and pcDNA3.1-NLRP3 groups. The study showed that miR-495 and miR-551a suppressed the invasion and migration of human gastric cancer cells by directly mediating with phosphatase of regenerating liver-3 [43]. MiR-22 restrains apoptosis and improves cell activity in endothelial cell (EC) injury under coronary heart disease (CHD) stress, and the role of NLRP3 is the opposite [44]. Moreover, the NLRP3 inflammasome regulates contrast-media-induced acute kidney damage through controlling cell apoptosis [45]. In addition, the NLRP3 inflammasome is up-modulated in myocardial fibroblasts postmyocardial infarction and might be an important contributor to development of infarct size during I/R [46].

\section{Conclusion}

Collectively, our study demonstrated that miR-495 ameliorated CMEC injury and inflammation reaction through suppressing the NLRP3 inflammasome signaling pathway. The mechanisms underlying the inhibitory effect of miR- 495 may be related to the regulation of the NLRP3 inflammasome. The findings obtained in this study provide a significant insight into the protective effect of miR-495 and suggest a new approach of utilizing the antiinflammatory effects of miR-495 to treat CMEC injury and inflammatory reaction. However, 


\section{Cellular Physiology Cell Physiol Biochem 2018;49:798-815 \begin{tabular}{ll|l} 
DOI: 10.1159/000493042 & $\begin{array}{l}\text { O 2018 The Author(s). Published by S. Karger AG, Basel } \\
\text { www.karger.com/cpb }\end{array}$
\end{tabular}

the targeting relationship requires further investigation to confirm our conclusion. Further, knockout studies cannot be added in our study due to a lack of time and energy; however, these studies could be conducted as part of future research.

\section{Acknowledgements}

This work was supported by Youth Foundation of Guizhou Provincial People's Hospital (No. GZSYQN [2016]01). We would like to give our sincere appreciation to the reviewers for their helpful comments on this article.

\section{Disclosure Statement}

The authors have declared that no competing interests exist.

\section{References}

-1 Wu XD, Zhang ZY, Sun S, Li YZ, Wang XR, Zhu XQ, Li WH, Liu XH: Hypoxic preconditioning protects microvascular endothelial cells against hypoxia/reoxygenation injury by attenuating endoplasmic reticulum stress. Apoptosis 2013;18:85-98.

2 Enoksson M, Lyberg K, Moller-Westerberg C, Fallon PG, Nilsson G, Lunderius-Andersson C: Mast cells as sensors of cell injury through IL-33 recognition. J Immunol 2011;186:2523-2528.

-3 Qian J, Jiang F, Wang B, Yu Y, Zhang X, Yin Z, Liu C: Ophiopogonin D prevents H2O2-induced injury in primary human umbilical vein endothelial cells. J Ethnopharmacol 2010;128:438-445.

-4 Powers SK, Quindry JC, Kavazis AN: Exercise-induced cardioprotection against myocardial ischemiareperfusion injury. Free Radic Biol Med 2008;44:193-201.

5 Hausenloy DJ, Yellon DM: Myocardial ischemia-reperfusion injury: a neglected therapeutic target. J Clin Invest 2013;123:92-100.

-6 Frangogiannis NG: The inflammatory response in myocardial injury, repair, and remodelling. Nat Rev Cardiol 2014;11:255-265.

7 Ahluwalia A, Narula J, Jones MK, Deng X, Tarnawski AS: Impaired angiogenesis in aging myocardial microvascular endothelial cells is associated with reduced importin alpha and decreased nuclear transport of HIF1 alpha: mechanistic implications. J Physiol Pharmacol 2010;61:133-139.

-8 Zhou B, Honor LB, He H, Ma Q Oh JH, Butterfield C, Lin RZ, Melero-Martin JM, Dolmatova E, Duffy HS, Gise A, Zhou P, Hu YW, Wang G, Zhang B, Wang L, Hall JL, Moses MA, McGowan FX, Pu WT: Adult mouse epicardium modulates myocardial injury by secreting paracrine factors. J Clin Invest 2011;121:1894-1904.

-9 Chen ZM, Jiang LX, Chen YP, Xie JX, Pan HC, Peto R, Collins R, Liu LS, group Cc: Addition of clopidogrel to aspirin in 45, 852 patients with acute myocardial infarction: randomised placebo-controlled trial. Lancet 2005;366:1607-1621.

10 Grivennikov SI, Greten FR, Karin M: Immunity, inflammation, and cancer. Cell 2010;140:883-899.

$\checkmark 11$ Ye Y, Perez-Polo JR, Qian J, Birnbaum Y: The role of microRNA in modulating myocardial ischemiareperfusion injury. Physiol Genomics 2011;43:534-542.

12 Ji X, Takahashi R, Hiura Y, Hirokawa G, Fukushima Y, Iwai N: Plasma miR-208 as a biomarker of myocardial injury. Clin Chem 2009;55:1944-1949.

$>13$ Jiang X, Huang H, Li Z, He C, Li Y, Chen P, Gurbuxani S, Arnovitz S, Hong GM, Price C, Ren H, Kunjamma RB, Neilly MB, Salat J, Wunderlich M, Slany RK, Zhang Y, Larson RA, Le Beau MM, Mulloy JC, Rowley JD, Chen J: MiR-495 is a tumor-suppressor microRNA down-regulated in MLL-rearranged leukemia. Proc Natl Acad Sci U S A 2012;109:19397-19402.

14 Chu H, Chen X, Wang H, Du Y, Wang Y, Zang W, Li P, Li J, Chang J, Zhao G, Zhang G: MiR-495 regulates proliferation and migration in NSCLC by targeting MTA3. Tumour Biol 2014;35:3487-3494.

15 Tschopp J, Schroder K: NLRP3 inflammasome activation: The convergence of multiple signalling pathways on ROS production? Nat Rev Immunol 2010;10:210-215. 


\section{Cellular Physiology Cell Physiol Biochem 2018;49:798-815 \begin{tabular}{l|l} 
DOI: 10.1159/000493042 & $\begin{array}{l}\text { O 2018 The Author(s). Published by S. Karger AG, Basel } \\
\text { www.karger.com/cpb }\end{array}$
\end{tabular}

16 Wang X, Jiang W, Yan Y, Gong T, Han J, Tian Z, Zhou R: RNA viruses promote activation of the NLRP3 inflammasome through a RIP1-RIP3-DRP1 signaling pathway. Nat Immunol 2014;15:1126-1133.

17 Chen W, Zhao M, Zhao S, Lu Q, Ni L, Zou C, Lu L, Xu X, Guan H, Zheng Z, Qiu Q: Activation of the TXNIP/ NLRP3 inflammasome pathway contributes to inflammation in diabetic retinopathy: a novel inhibitory effect of minocycline. Inflamm Res 2017;66:157-166.

18 Liu Y, Lian K, Zhang L, Wang R, Yi F, Gao C, Xin C, Zhu D, Li Y, Yan W, Xiong L, Gao E, Wang H, Tao L: TXNIP mediates NLRP3 inflammasome activation in cardiac microvascular endothelial cells as a novel mechanism in myocardial ischemia/reperfusion injury. Basic Res Cardiol 2014;109:415.

19 Oyama J, Blais C, Jr., Liu X, Pu M, Kobzik L, Kelly RA, Bourcier T: Reduced myocardial ischemia-reperfusion injury in toll-like receptor 4-deficient mice. Circulation 2004;109:784-789.

-20 Livak KJ, Schmittgen TD: Analysis of relative gene expression data using real-time quantitative PCR and the 2(-Delta Delta C(T)) Method. Methods 2001;25:402-408.

-21 Moens AL, Claeys MJ, Timmermans JP, Vrints CJ: Myocardial ischemia/reperfusion-injury, a clinical view on a complex pathophysiological process. Int J Cardiol 2005;100:179-190.

22 Ruan W, Xu JM, Li SB, Yuan LQ, Dai RP: Effects of down-regulation of microRNA-23a on TNF-alpha-induced endothelial cell apoptosis through caspase-dependent pathways. Cardiovasc Res 2012;93:623-632.

23 Laukkanen JA, Kurl S, Rauramaa R, Lakka TA, Venalainen JM, Salonen JT: Systolic blood pressure response to exercise testing is related to the risk of acute myocardial infarction in middle-aged men. Eur J Cardiovasc Prev Rehabil 2006;13:421-428.

-24 de Lemos JA, Drazner MH, Omland T, Ayers CR, Khera A, Rohatgi A, Hashim I, Berry JD, Das SR, Morrow DA, McGuire DK: Association of troponin T detected with a highly sensitive assay and cardiac structure and mortality risk in the general population. JAMA 2010;304:2503-2512.

25 Tzivoni D, Koukoui D, Guetta V, Novack L, Cowing G, Investigators CS: Comparison of Troponin T to creatine kinase and to radionuclide cardiac imaging infarct size in patients with ST-elevation myocardial infarction undergoing primary angioplasty. Am J Cardiol 2008;101:753-757.

-26 Wang Q, Liu F, Yang X, Wang K, Wang H, Deng X: Sensitive point-of-care monitoring of cardiac biomarker myoglobin using aptamer and ubiquitous personal glucose meter. Biosens Bioelectron 2015;64:161-164.

-27 Bernardino L, Agasse F, Silva B, Ferreira R, Grade S, Malva JO: Tumor necrosis factor-alpha modulates survival, proliferation, and neuronal differentiation in neonatal subventricular zone cell cultures. Stem Cells 2008;26:2361-2371.

28 Maekawa N, Wada H, Kanda T, Niwa T, Yamada Y, Saito K, Fujiwara H, Sekikawa K, Seishima M: Improved myocardial ischemia/reperfusion injury in mice lacking tumor necrosis factor-alpha. J Am Coll Cardiol 2002;39:1229-1235.

29 Piccini A, Carta S, Tassi S, Lasiglie D, Fossati G, Rubartelli A: ATP is released by monocytes stimulated with pathogen-sensing receptor ligands and induces IL-1beta and IL-18 secretion in an autocrine way. Proc Natl Acad Sci U S A 2008;105:8067-8072.

-30 O’Brien LC, Mezzaroma E, Van Tassell BW, Marchetti C, Carbone S, Abbate A, Toldo S: Interleukin-18 as a therapeutic target in acute myocardial infarction and heart failure. Mol Med 2014;20:221-229.

-31 McMullen NT, Goldberger B, Glaser EM: Postnatal development of lamina III/IV nonpyramidal neurons in rabbit auditory cortex: quantitative and spatial analyses of Golgi-impregnated material. J Comp Neurol 1988;278:139-155.

-32 Inoue M, Williams KL, Gunn MD, Shinohara ML: NLRP3 inflammasome induces chemotactic immune cell migration to the CNS in experimental autoimmune encephalomyelitis. Proc Natl Acad Sci U S A 2012;109:10480-10485.

33 Kleinbongard P, Schulz R, Heusch G: TNFalpha in myocardial ischemia/reperfusion, remodeling and heart failure. Heart Fail Rev 2011;16:49-69.

34 Schroder K, Zhou R, Tschopp J: The NLRP3 inflammasome: a sensor for metabolic danger? Science 2010;327:296-300.

35 Toldo S, Mezzaroma E, Van Tassell BW, Farkas D, Marchetti C, Voelkel NF, Abbate A: Interleukin-1beta blockade improves cardiac remodelling after myocardial infarction without interrupting the inflammasome in the mouse. Exp Physiol 2013;98:734-745.

-36 Bracey NA, Beck PL, Muruve DA, Hirota SA, Guo J, Jabagi H, Wright JR, Jr., Macdonald JA, Lees-Miller JP, Roach D, Semeniuk LM, Duff HJ: The Nlrp3 inflammasome promotes myocardial dysfunction in structural cardiomyopathy through interleukin-1beta. Exp Physiol 2013;98:462-472. 


\section{Cellular Physiology Cell Physiol Biochem 2018;49:798-815

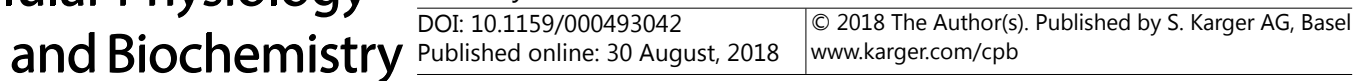 \\ Zhou et al.: miR-495 Acts on Mmvecs Via NLRP3 Inflammasome Pathway}

-37 Doyle SL, Campbell M, Ozaki E, Salomon RG, Mori A, Kenna PF, Farrar GJ, Kiang AS, Humphries MM, Lavelle EC, O'Neill LA, Hollyfield JG, Humphries P: NLRP3 has a protective role in age-related macular degeneration through the induction of IL-18 by drusen components. Nat Med 2012;18:791-798.

38 Boini KM, Hussain T, Li PL, Koka S: Trimethylamine-N-Oxide Instigates NLRP3 Inflammasome Activation and Endothelial Dysfunction. Cell Physiol Biochem 2017;44:152-162.

-39 Deng Y, Han X, Yao Z, Sun Y, Yu J, Cai J, Ren G, Jiang G, Han F: PPARalpha Agonist Stimulated Angiogenesis by Improving Endothelial Precursor Cell Function Via a NLRP3 Inflammasome Pathway. Cell Physiol Biochem 2017;42:2255-2266.

-40 Wang Y, Xu CF, Liu YJ, Mao YF, Lv Z, Li SY, Zhu XY, Jiang L: Salidroside Attenuates Ventilation Induced Lung Injury via SIRT1-Dependent Inhibition of NLRP3 Inflammasome. Cell Physiol Biochem 2017;42:34-43.

-41 Gong DM, Zhang YL, Chen DY, Hong LJ, Han F, Liu QB, Jiang JJ, Lu YM: Endothelial GPR124 Exaggerates the Pathogenesis of Atherosclerosis by Activating Inflammation. Cell Physiol Biochem 2018;45:547-557.

-42 Kim HJ, Lee DW, Ravichandran K, D OK, Akcay A, Nguyen Q, He Z, Jani A, Ljubanovic D, Edelstein CL: NLRP3 inflammasome knockout mice are protected against ischemic but not cisplatin-induced acute kidney injury. J Pharmacol Exp Ther 2013;346:465-472.

43 Li Z, Cao Y, Jie Z, Liu Y, Li Y, Li J, Zhu G, Liu Z, Tu Y, Peng G, Lee DW, Park SS: miR-495 and miR-551a inhibit the migration and invasion of human gastric cancer cells by directly interacting with PRL-3. Cancer Lett 2012;323:41-47.

44 Huang WQ, Wei P, Lin RQ, Huang F: Protective Effects of Microrna-22 Against Endothelial Cell Injury by Targeting NLRP3 Through Suppression of the Inflammasome Signaling Pathway in a Rat Model of Coronary Heart Disease. Cell Physiol Biochem 2017;43:1346-1358.

45 Shen J, Wang L, Jiang N, Mou S, Zhang M, Gu L, Shao X, Wang Q, Qi C, Li S, Wang W, Che X, Ni Z: NLRP3 inflammasome mediates contrast media-induced acute kidney injury by regulating cell apoptosis. Sci Rep 2016;6:34682.

-46 Sandanger O, Ranheim T, Vinge LE, Bliksoen M, Alfsnes K, Finsen AV, Dahl CP, Askevold ET, Florholmen G, Christensen G, Fitzgerald KA, Lien E, Valen G, Espevik T, Aukrust P, Yndestad A: The NLRP3 inflammasome is up-regulated in cardiac fibroblasts and mediates myocardial ischaemia-reperfusion injury. Cardiovasc Res 2013;99:164-174. 